\title{
THE INFLUENCE OF HYPNOTHERAPY ON THE COACHING ACHIEVEMENT OF ATHLETES IN JUMP AND THROW SPORTS
}

\author{
$\operatorname{Amirzan}^{1 *}$, Indra Kasih ${ }^{2}$ \\ Correspondence: ${ }^{1}$ Universitas Jabar Gafur, Aceh, Indonesia \\ ${ }^{2}$ Universitas Negeri Medan, Medan, Indonesia \\ E-mail: mirzan_masry@yahoo.co.id
}

\begin{abstract}
This research used experimental design in the form of one group pre-post design, aimed to find out; the effect of hypnotherapy on fostering athletes' achievements in jump and throw sports. The population was all athletes in the athletic sport of jumping and throwing of 23 people. The technique of determining the sample by positive sampling, while the technique of data analysis used descriptive frequency analysis and paired sample test analysis (paired t-test) through the SPSS program version 20.00 at a significant level $\alpha=0.05$. The results showed that "the influence of hypnotherapy on fostering athlete achievements in jump and throw sports, t-test values of $\mathrm{t}$-count of 2,354 and t-table $(22 ; 0.05)$ of 1,717 with a significant level of $0.028(0.028<\alpha=0.05)$ or ( $t$ _count $>t$ table) The conclusion of this study was there is an influence of hypnotherapy on fostering athlete's achievement suggestibility (tance level test) in jump and throw of athletic sports.
\end{abstract}

\section{Keywords: Hypnotherapy, Athlete's Achievement Suggestibility}

\section{Introduction}

Development of athlete's achievement is no longer imposed only on the coach alone, it is not possible for a coach to function multi-use, for example in addition to technical trainers he also functions as a physical trainer, mental coach or sports psych oater, club manager, health and therapeutic expert and other things required in every achievement coaching activity.

If this happens, it can be imagined how impossible a glorious achievement is expected. Nowadays the training of each sport must involve various fields of expertise as a co-trainer and assistant trainer such as the involvement of psych oater, various specialist doctors, nutritionists, therapists, sports academics, researchers, observers and other experts.

Setyobroto (2001) The success of athlete's development does not only depend on the talents, abilities of the athlete and the expertise of the coach; a variety of factors need to be considered, because achievement is the result of a coaching system, namely integration between all components as a whole system intended to produce the highest athlete's achievement. Elements which interact in the coaching process need special attention, namely: (1) training, (2) athletes, (3) scientists and (4) coaches / administrators. 
Coaching conducted on athletes in general is an increase in technique, physical and mental abilities. Of the three factors, the coaches usually focus more on technical and physical training activities and mental disregard, isn't mental also very influential on athlete's achievement, because a disturbed mentality will be reflected in the athlete's appearance before and during the competition and clearly visible techniques displayed inversely when viewed during coaching. The focus of this study is to determine the level of suggestibility of each athlete and testing the effectiveness or effect of hypnosis on the athlete's mental development.

In the book Hypnosport, Les Cunningham writes that Hypnosport has been widely used in sports, even in competitions at the Olympics since 1956. Suwandi (2013) while most hypnosis research focuses on hypnotherapy, there is also evidence that hypnosis can help you master or perfect skills, giving you extra therapy. The targets of hypnosis applications in sports which are often referred to as hypnosports include the following:

\section{Confidence (Self Confidence)}

Building self-confidence is the same as eliminating fear, for athletes, is very important especially when approaching the match day. Because of high selfconfidence that is the best technique, tactics and strategy can emerge and an athlete. Tiger Woods can prove, visualization is effective self-hypnosis techniques that can help athletes perform better. A gymnast can visualize his routine movements repeatedly within himself or her animal. A basketball player can visualize the throw shot hundreds of times and various positions in him perfectly.

Self-confidence is a unique and valuable part of life, Kushartanti (2009). There are people who consider themselves full of self-confidence suddenly feel that their confidence is not as big as what they had thought, so they lack confidence where for the world feels as an unsafe and difficult place.

\section{Muscle Work Programming Education. Health and Recreation}

Marilyn King (world-class pen athlete who holds a gold medal) at that time Marilyn had to be hospitalized for some time, even though the Olympiad preparation time was only a few months away. While in the hospital, Marilyn practiced imagery, replacing physical training with imaginary running. He imagined as if he really did a running exercise on the running track and also imagined the actual race activities including the shadow of his success in winning the running race. He imagined the atmosphere of the stage when he was put on a gold medal. Besides that he also imagined auditory and kinesthetic, so he could hear the roar of the audience while watching him run. He also imagined the motion of his footsteps, even though he was lying in the hospital. Agus, R. and Suseno (2012).

\section{Directing Visualization and Focus}

Visualization in the world of sports, namely inviting athletes or people to imagine themselves without direction and ignoring (conditions of mind waves) the 
condition of the athlete when imagining where the athlete is really in a very focused and deep condition with maximum inspiration. The role of the teacher is to apply the techniques and skills of visualization in students as an alternative method in increasing the effort to solve problems, Lasiun (2016). If someone is able to visualize themselves in a trance condition, then in the science of hypnosis is called self-hypnosis. This is the purpose of self-hypnosis so that all sports people are able to program their brain to command their muscles and mental states to be desired.

\section{Managing Stress}

Sports psychologists often teach athletes how to control them in dialogue (self-talk), Lindawati (2014), so that they can switch negative thoughts into selffulfilling, or develop positive things. This is a very good strategy for every beginner athlete. Stress is a symptom of psychology that we often encounter in daily life, in which every individual must have experienced it, Rahmi (2013). The main behavioral symptoms of stress, one of which is decreased learning achievement and productivity of a person, Rahmi (2013)

\section{Method}

This research is an experimental research using the "One-Group Pretest Posttest design" method, Sugiyono (2014), as follows:

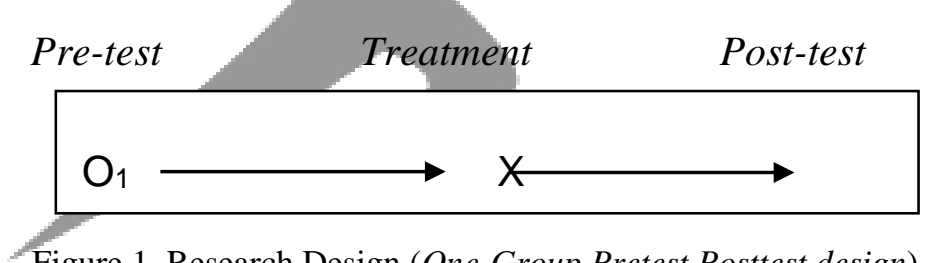

Figure 1. Research Design (One-Group Pretest Posttest design)

\section{Journal Physical Education, Health and Recreation}

The subjects of the research were Dispora fostered athletes from Pidie Jaya-Aceh Regency with 23 jump and throw athletic sports. The technique of determining the sample used positive sampling and analysis of SPSS program statistical test data version 20.00. The data analysis technique used t-test statistical infrential at the $5 \%$ significance level, to find out whether there were no differences, infrentially testing the hypothesis with t-test analysis. Hypothesis using t-test with a significant level ( $\square=0.01$ or $\square=0.05$ ) then look for a table with the terms $\mathrm{dk}=$ n-1.

\section{Discussion}

Empirical data obtained and analyzed in this study include the results of the pretest conducted before being given treatment with the hypnotherapy and posttest models when administering treatment with the hypnotherapy model for the experimental group namely athletes with throwing and jumping athletes as the total of 23 athletes. 
Table 1. Summary of Descriptive Analysis Results on Research Data

\begin{tabular}{lcc}
\multicolumn{1}{c}{ Statistic } & \multicolumn{2}{c}{ Experiment group } \\
\cline { 2 - 3 } & Pretest & Post-test \\
\hline Sample & 23 & 23 \\
\hline Rata - rata (mean) & 17.4457 & 19.9065 \\
\hline Simpangan baku (std. & 12.20090 & 14.72284 \\
Deviation) & & 216.762 \\
\hline Varians (variance) & 148.862 & 43.40 \\
\hline Rentang (range) & 33.65 & 1.60 \\
\hline Minimum & 1.35 & 45.00 \\
\hline Maximum & 35.00 & 457.85 \\
\hline Jumlah total (sum) & 401.25 & \\
\hline Source: IBM SPSS Statistics version 20.00 & &
\end{tabular}

The results of paired t-test analysis for the experimental group pretest obtained t-count value of 2.354 and t-table $(22 ; 0.05)$ of 1.717 with a significant level of $0.028(0.028<\alpha=0.05)$ or ( $\mathrm{t}$-count $>\mathrm{t}$-table), or $\mathrm{H}_{0}$ was rejected and $\mathrm{H}_{1}$ received. Based on these results, it can be concluded that there are differences in the pretest and posttest of the experimental group, or in other words ( $t$ _count> t_table). Showing the meaning of hypnotherapy is an important model of coaching achievement. In line with the results of Annisa Fitri Aun's research, based on the results of the study and discussion of the effect of hypnotherapy on the decrease in pain intensity is very significant, Aun (2015). In the construction of sports achievements, any condition can occur in this case the physical athletes. Starting from injuries, psychological burdens, mental competition, excessive anxiety, match hours that has not been much. These problems will greatly help athletes if given hypnotherapy.

\section{Conclusion}

Based on the results of data analysis and discussion which has been put forward, it can be concluded "there is a hypnotherapy effect on fostering athlete's achievement (tance level test) in jumping and throwing of athletic sports, t-test value obtained for the t-value of 2.354 and ttable $(22 ; 0.05)$ of 1.717 with a significant level of $0.028(0.028<\alpha=0.05)$ or ( $\mathrm{t}$ _count $>\mathrm{t}$ _table) .

\section{References}

Agus, R. dan Suseno, A. 2012. Penggunaan Quantm GIS dalam Sistem Informasi Geografis. Quantum GIS.

Aun, A. F, 2015. Pengaruh Hipnoterapi Terhadap Tingkat Nyeri Dismenore Di Smpn 16 Pontianak Tahun 2015 Program Studi Ilmu Keperawatan. Nursing Student Tanjungpura University.

Kushartanti, A, 2009. Perilaku Menyontek ditinjau dari Kepercayaan Diri. Indigenious, Jurnal Imliah Berkala Psikologi, 11, 38-46.

Lasiun, M, 2016. Keberkesanan Kaedah Visualisasi: Meningkatkan Keupayaan

Menyelesaikan Masalah Matematik Berayat. Proceedings of the ICECRS, 1(1), 687-698. https://doi.org/10.21070/picecrs.v1i1.542

Lindawati, R, 2014. Work Stress ( Stres Kerja ). Widyaiswara Pusdiklat Bea Dan

PJKR

http://jurnal.unimed.ac.id/2012/index.php/jpehr 
Cukai.

Rahmi, N, 2013. Hubungan Tingkat Stres Dengan Prestasi Belajar Mahasiswa Tingkat Ii Prodi D-Iii Kebidanan Banda Aceh Jurusan Kebidanan Poltekkes Kemenkes Nad Ta. 2011/2012. Jurnal Ilmiah STIKes U'Budiyah, 2(1), 6676.

Setyobroto, S, 2001. Mental Training. Jakarta: Percetakan Solo. sugiyono, 2014. Metode penelitian. Metode Penelitian.

Suwandi, A, 2013. Turbo Speed Hipnotis. Titik Media Publisher.

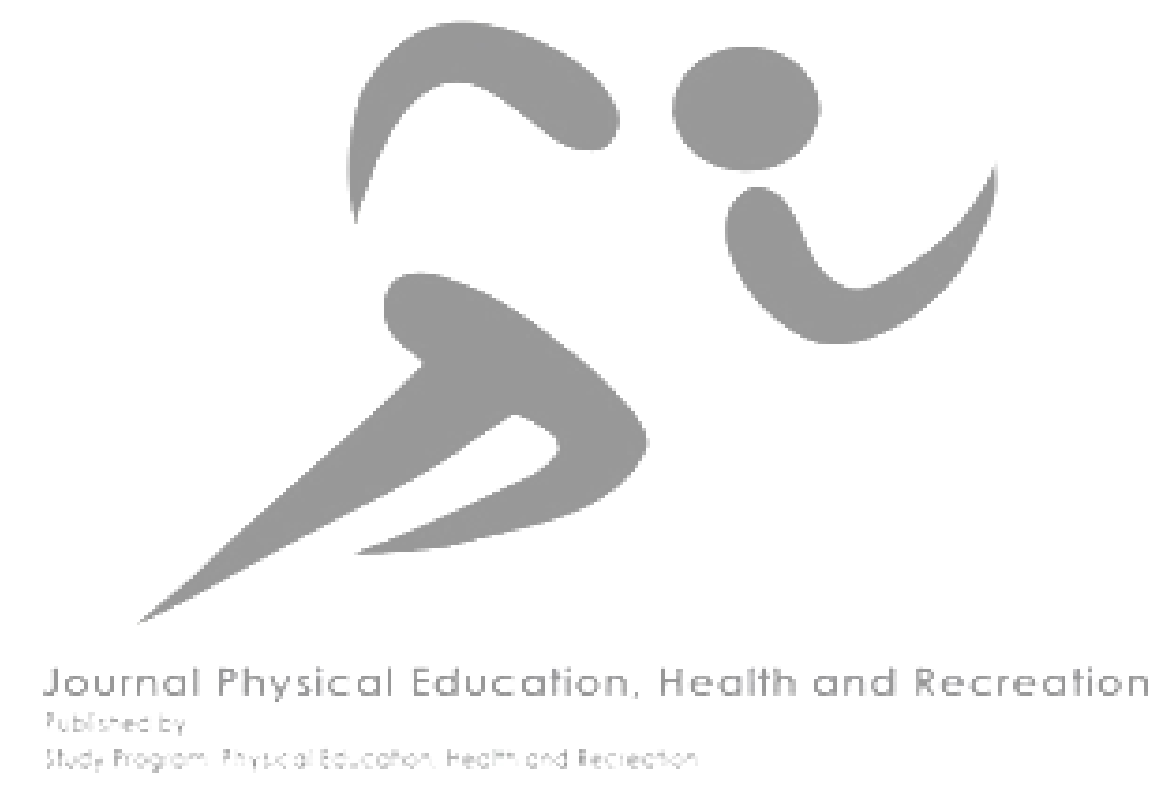

